\title{
Forensicssciences in Brazil. Toward a Wide Horizon
}

\author{
Raimundo Alberto Tostes* \\ Department of Food Engineering, , Brazil \\ *Corresponding author: Raimundo Alberto Tostes, Department of Food Engineering, Paraná State, Brazil, Campus Jandaia do Sul
}

Submission: 悳 February 13, 2018; Published: 監 April 05, 2018

\section{Opinion}

The use of technical, scientific, and methodological resources to aidjustice incresead exponentially through out the twentieth century. Thus, forensic science has been essentialtopromote a formidable body of knowledge and giving the methodological accuracy and reliability. Some vetforensics interfaces in Brazil are worthnoting, such as qualityanalysis in food industry, fight against animal traffic king and wildlife threats, and all efforts to claimsa new status to animal welfare-mainly pets, and last but not least the endeavor to establish a high level of organization as reference specialty.

Forensic sciences have experienced a remarkable development in Brazil in recentyears in several areas, including veterinary medicine. Brazil is among the 10 biggest global economiesand continues to be an important animal protein producer in the world. This ensures to Brazilan enormous strategic importance in world food security. However, has increase concerns about food safety in the world. So, is also important that companies and agents involved with animal products be aware about the fact that crimes andlapses can be demonstrated through use of techniques and procedures advocated by the forensic sciences.

A recent and significative example is the investigation triggered by the Brazilian Federal Police against fraud and bribes in some meatindustry, known as "Operation Weak Flesh". The exuberant and diversified brazilian fauna also implies in efforts and resources to fight againstan intense and criminal animal traffic. The brazilian territory continental dimensionis combined with the difficulty to monitoring borders. The hot spots borders that requires attention to the sanitary surveillance system are the same to criminal traffic, including weapons, drugs and animals. Therefore, vet forensics is aligned with a continental agenda to combatorganized crime. Other prominent role of brazilian vet forensicsisin defense of pets and animal welfare in broad sense. According the Brazilian Association of the Industry of Products for Pets (ABINPET), the pet food and products market in Brazil presents a very optimistic scenario, from a technical and economic point ofview. In Brazil, is the domestic pet market isstablean daims for constant improvement, to meet the expectations of a highly demanding public. Has been emerging new industries andemploymentopportunities. Brazil is the world's third largest pet market, with a market share of $6.3 \%$, behind the United States (41.8\%) and the United Kingdom (6.5\%). There fore, the increased pets number has raised the availability of veterinary medical services, the demand for specialized services and, as a natural consequence, greater relevance in assessing conditions of animal abuse and criteria for the classification of these crimes.

In 2003, Conselho Regional de Medicina Veterinária [Brazilian Veterinary Medicine Council] recognizes Veterinary Forensics as oficial veterinary specialty. Other important brazilian for ensicsvet land mark is the Associação Brasileira de Medicina Veterinária LegalABMVL [Brazilian Veterinary Forensics Association] foundation, in 2009 in São Paulo. ABMVL became a touchs tone to the specialty in Brazil. The association has organized three importantint ernational meetings (2013, 2015 and 2017), a pioneer interinstitutional project-Legal Fauna Project (sponsored by government research funds), and accepted the responsibility of spreading the specialty among students and professionals. ABMVL collaborated to publish in 2017 the Treatise of Veterinary Forensics, as a result of the participation of more than 30 researchers from important brazilian institutions linked to the me besides international partners. The first book is this are a published originally in portuguese language, including data about vet forensic reality in Brazil as well discussions about brazilian legislation.

Despite all the seanalysis elements, vet forensics remains as an incipient area in Brazil and demand efforts to consolidate it. On the other hand, the braziliang overnment policy in flicts today the biggest dismantlement in the financing of research and investments in science and technology. Multiple actionsch allenge the for ensicsvets future globally. Confronted with the fierceurgency of now, brazilian vet for ensich as an important role in provide and extend legal cover to animal protection, put the government under pressure to expand the infrastructure of the labs official network, demand investment and collaborates to promote systematic professional training and qualification. 
(c) (i) Creative Commons Attribution 4.0 International License

For possible submissions Click Here

Submit Article

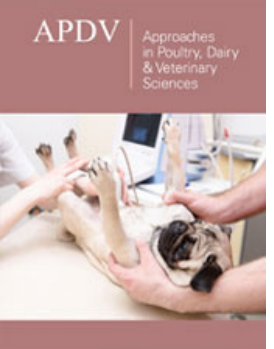

Approaches in Poultry, Dairy \& Veterinary Sciences

\section{Benefits of Publishing with us}

- High-level peer review and editorial services

- Freely accessible online immediately upon publication

- Authors retain the copyright to their work

- Licensing it under a Creative Commons license

- Visibility through different online platforms 